\section{Vincristine-induced Autonomic Neuropathy}

Neurological adverse effects are known to complicate vincristine treatment. In occasional reports of bowel and bladder disturbance it has not been possible to incriminate autonomic neuropathy. We report here three patients with symptoms and signs which could be ascribed to vincristine-induced autonomic neuropathy.

\section{Case Reports}

Case 1.-A 75-year-old man presented with recurrent Hodgkin's disease Chemotherapy with modified MOPP (intravenous mustine $6 \mathrm{mg} / \mathrm{m}^{2}$ and vincristine (Oncovin) $1.4 \mathrm{mg} / \mathrm{m}^{2}$ on days 1 and 8 ; oral procarbazine $100 \mathrm{mg}$ / $\mathrm{m}^{2}$ and prednisolone $40 \mathrm{mg} /$ day for 14 days; 28 days between each course) was started. About 10 days after his first course he developed symptomatic postural hypotension, his blood pressure being $110 / 80 \mathrm{~mm} \mathrm{Hg}$ lying and $70 / 40 \mathrm{~mm} \mathrm{Hg}$ standing. The Valsalva response was characteristic of autonomic neuropathy. He also had marked peripheral neuropathy. Slow spontaneous improvement occurred and chemotherapy was resumed using vinblastine instead of vincristine.

Case 2.-A 77-year-old man presented with diffuse lymphocytic lymphoma. Cyclical chemotherapy was begun with COPAd (intravenous cyclophosphamide $400 \mathrm{mg} / \mathrm{m}^{2}$ and vincristine $1.4 \mathrm{mg} / \mathrm{m}^{2}$ on days 1 and 8 ; oral prednisolone $40 \mathrm{mg} /$ day for 14 days; intravenous adriamycin $40 \mathrm{mg} / \mathrm{m}^{2}$ on day 1 ; 28 days between each course). One week after his first course he developed severe postural hypotension (blood pressure $160 / 80 \mathrm{~mm} \mathrm{Hg}$ lying and $90 / 50$ $\mathrm{mm}$ Hg standing). The Valsalva response was abnormal. Over the next few days he also developed peripheral neuropathy. His symptoms improved over the next two weeks and chemotherapy was continued using vinblastine instead of vincristine.

Case 3.-A 56-year-old man presented with generalized Hodgkin's disease and received three courses of modified MOPP. He was admitted with generalized weakness, constipation, and retention of urine. Clinical and radiological examination showed paralytic ileus. His blood pressure was $110 / 70 \mathrm{~mm} \mathrm{Hg}$ lying and $80 / 20 \mathrm{~mm} \mathrm{Hg}$ standing. Myoclonic jerks were observed and he had an extensive peripheral neuropathy. Spontaneous improvement occurred over three to four weeks. Chemotherapy was restarted, substituting vinblastine for vincristine, but he died of septicaemia

\section{Comment}

Neurotoxicity is a well recognized adverse effect of vincristine treatment. The predominant change is an axonal neuropathy, ${ }^{1}$ which usually takes the form of peripheral neuropathy, though central nervous system abnormalities have been described. Constipation commonly occurs and bladder disturbance has been reported, ${ }^{2}$ and it has been suggested that these features (which usually post-date peripheral neuropathy) are a result of autonomic nerve damage. ${ }^{3}$

In primary autonomic degeneration ${ }^{4}$ sphincter disturbance usually precedes other neurological symptoms-for example, postural hypotension, abnormal Valsalva response, defective sweating, episodic altered consciousness, and myoclonic jerks. Two patients (cases 1 and 2) showed no evidence of sphincter disturbance, though there was profound postural hypotension and abnormal Valsalva responses. Both patients also developed peripheral neuropathy. In case 3 bladder and bowel atony were pronounced, and postural hypotension, myoclonic jerks, and severe symptomatic peripheral neuropathy were observed.

Postural hypotension is common in the elderly, ${ }^{5}$ and this, together with the onset of illness and relative immobility, might have contributed to the findings in cases 1 and 2 . Vincristine toxicity is worse with increasing dosage and frequency of administration, but elderly patients are also more sensitive to the toxic effects of all cytotoxic drugs, and the doses of such agents may have to be modified accordingly. Certainly our two older patients (cases 1 and 2) had each received only $5 \mathrm{mg}$ vincristine in two doses given a week apart. The third patient (aged 56) received six 2-mg doses of vincristine over three months.

All symptoms improved three to four weeks after stopping vincristine, but despite some improvement postural hypotension and peripheral neuropathy persisted. In each patient treatment was changed to vinblastine without deterioration in neurological status.

In the light of our findings regular estimation of blood pressure for exaggerated postural fall may give early warning of vincristine neurotoxicity.

We thank Professor J. Richmond for his helpful criticism and advice and Dr. F. E. Neal and Dr. I. G. Emmanuel for allowing us to report details of patients under their care.

${ }^{1}$ Sandler, S. G., Tobin, W., and Henderson, E. S., Neurology, 1969, 19, 367.

${ }^{2}$ Gottlieb, R. J., and Cuttner, R. J., Cancer, 1971, 28, 674

${ }^{3}$ Lancet, 1973, 1, 980.

${ }^{4}$ Bannister, R., Lancet, 1971, 2, 175.

${ }^{5}$ British Medical fournal, 1973, 4, 246.

Academic Division of Medicine, Royal Hospital, Sheffield S1 3SR B. W. HANCOCK, D.C.H., M.R.c.P., Lecturer A. NAYSMITH, M.B., B.SC., Senior House Officer

\section{Gastroenteritis Causing Failure of Oral Contraception}

The use of oral contraceptive preparations has gradually increased over the past 10 years and they now probably account for about $20 \%$ of all contraceptive measures used by married women in the U.K. ${ }^{1}$ Perhaps the most important factor in popularizing oral contraception has been its efficiency, with pregnancy rates of only 0.1 to $1.0 \%$ in various reports. ${ }^{2}$ Most failures in the past have been attributed to the patient forgetting to take the tablets regularly. Little reference has been made to pregnancy occurring as a result of non-absorption of the oral contraceptive due to gastroenteritis associated with diarrhoea, vomiting, or both. In a series of 38 cases of pregnancy occurring in women using a combined oestrogen-progestogen preparation Rutenskold ${ }^{3}$ attributed the pregnancy to vomiting or diarrhoea in five cases and observed that pregnancy was due to failure of therapeutic effect of the preparation in 15 cases. In our experience "tablet failure" is comparatively rare, and we have seen eight patients taking oral contraceptives in whom pregnancy occurred associated with gastrointestinal disturbance. We present here details of these cases.

\section{Patients}

The relevant features of the eight patients are summarized in the table. Cases 5,6 , and 8 were using a low-dose oestrogen contraceptive preparation and the remaining cases a medium-dose oestrogen preparation. ${ }^{4}$ All patients were quite sure that no tablets had been missed in spite of the gastrointestinal upset. Oral contraceptives had been used from two months to 36 months before the occurrence of the pregnancy. Six patients had been taking the tablets for more than 10 months. Three patients (cases 3,5, and 6) had diarrhoea only; two had been on holiday abroad and the diarrhoea was presumably due to change of diet or bacterial food poisoning. The remainin five patients suffered from diarrhoea and vomiting and seemed to have had

Details of Women who became Pregnant while Using Oral Contraceptives after Gastrointestinal Upset

\begin{tabular}{|c|c|c|c|c|c|}
\hline $\begin{array}{l}\text { Case } \\
\text { No. }\end{array}$ & $\begin{array}{l}\text { Oral Contraceptive } \\
\text { Preparation }\end{array}$ & $\begin{array}{c}\text { Duration of Use before } \\
\text { Pregnancy } \\
\text { (Months) }\end{array}$ & Symptoms & $\begin{array}{l}\text { Day of Cycle of Diarrhoea } \\
\text { and/or Vomiting }\end{array}$ & Result of Pregnancy \\
\hline $\begin{array}{l}1 \\
2 \\
3 \\
4 \\
5 \\
6 \\
7 \\
8\end{array}$ & $\begin{array}{l}\text { Norinyl-1 } \\
\text { Gynovlar-21 } \\
\text { Ovran } \\
\text { Minovlar } \\
\text { Ovranette } \\
\text { Microgynon } 30 \\
\text { Ovulen 50 } \\
\text { Ovranette }\end{array}$ & $\begin{array}{r}24 \\
12 \\
20 \\
36 \\
10 \\
3 \\
12 \\
2\end{array}$ & $\begin{array}{l}\text { Diarrhoee and vomiting } \\
\text { Diarrhoea and vomiting } \\
\text { Diarrhoea } \\
\text { Diarrhoea and vomiting } \\
\text { Diarrhoea } \\
\text { Diarrhoea } \\
\text { Diarrhoea and vomiting } \\
\text { Diarrhoea and vomiting }\end{array}$ & $\begin{array}{c}8-10 \\
15-16 \\
6-8 \\
12-15 \\
4-8 \\
3-5 \\
5-7 \\
7-8\end{array}$ & $\begin{array}{l}\text { Normal live birth } \\
\text { Termination } \\
\text { Termination } \\
\text { Termination } \\
\text { Termination } \\
\text { Termination } \\
\text { Normal live birth } \\
\text { Termination }\end{array}$ \\
\hline
\end{tabular}


a virus type of gastroenteritis. In two cases the symptoms were present for one day only while the other patients suffered for two or more days. Most of the patients developed symptoms after taking seven to 10 tablets in that particular cycle but in two cases more than 12 tablets had been taken and in one case only three tablets had been taken.

\section{Discussion}

Study of the oral contraceptives in common use shows that the leaflet which accompanies each packet of tablets warns the patient of the risk of omitting tablets and the action to be taken if this happens. In only $30 \%$ of preparations does the leaflet explain that if diarrhoea or vomiting occurs the contraceptive effect may be lost and pregnancy result: Anovlar-21, Minovlar, Eugynon 30, Minovlar ED, Gynovlar -21 Ovranette, and Minilyn.

Furthermore, in the Handbook of Contraceptive Practice, ${ }^{4}$ published by the Department of Health and Social Security, no mention is made of diarrhoea or vomiting in relation to failure of oral contraceptives. In our eight cases of pregnancy four patients were using preparations which did specifically mention the risks of gastrointestinal upsets, which must mean that they either did not read or did not understand the information given. Warnings of possible side effects and of causes of failure of the preparation are much better given verbally by the prescriber, and the risk of diarrhoea or vomiting should be emphasized.

1 Bone, M., Family Planning Services in England and Wales. London, H.M.S.O., 1973.

2 Swyer, G. I. M., et al., Population Studies, 24, Suppl. p. 37, 1970.

${ }^{3}$ Rutensköld, M., Acta Obstetricia et Gynecologica Scandinavica, 1971, 50, 203.

4 Carne, S., Chamberlain, G., and McEwan, J., Handbook of Contraceptive Practice. London, D.H.S.S., 1974.

\section{Department of Gynaecology, Bristol Royal Infirmary, Bristol} BS2 8HW

A. HOWARD JOHN, F.R.c.s., F.R.c.o.G., Consultant Obstetrician and Gynaecologist

A. JAMES JONES, M.B., M.R.C.o.G., Registrar in Obstetrics and Gynaecology

\section{Cerebral Oedema in Diabetic Ketoacidosis}

Raised intracranial pressure during the treatment of diabetic ketoacidosis is uncommon but can produce or prolong unconsciousness. ${ }^{12}$ Treatment-with parenteral urea, mannitol, glucocorticoids, or dexamethasone-has generally been unsuccessful. ${ }^{1}$ We describe a diabetic patient who developed cerebral oedema during the treatment of hyperglycaemic ketoacidosis but who recovered after dexamethasone.

\section{Case Report}

A 40-year-old man maintained on isophane insulin for 14 years was admitted

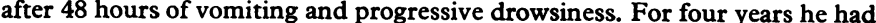
had moderate renal impairment (serum creatinine $725 \mu \mathrm{mol} / \mathrm{l}(8.2 \mathrm{mg} / 100$ $\mathrm{ml}$ )), hypertension, and advanced retinitis proliferans. On admission he was deeply unconscious, hyperventilating, and dehydrated. There were no focal neurological signs, and vitreous haemorrhages obscured the optic discs. Biochemical investigation confirmed severe hyperglycaemia, severe acidosis, and ketonuria (see fig.)

He was treated with hourly intramuscular insulin in low doses $^{3}$ and intravenous saline $0.9 \%$. Over three hours $500 \mathrm{ml}$ of $4.2 \%$ sodium bicarbonate was given. After 14 hours blood glucose had fallen to $19 \mathrm{mmol} / \mathrm{l}$ (344 $\mathrm{mg} / 100 \mathrm{ml}$ ), and he was no longer acidotic. He remained unconscious though responsive to pain. At 30 hours his level of consciousness was unchanged though biochemical values were normal. Sterile cerebrospinal fluid (C.S.F.) was obtained under pressure of $400 \mathrm{~mm} \mathrm{H}_{2} \mathrm{O}$ and it contained $0.045 \times 10^{9} / 1$ lymphocytes (glucose $2.6 \mathrm{mmol} / 1(46 \mathrm{mg} / 100 \mathrm{ml})$ ). Dexamethasone was given in an initial dose of $10 \mathrm{mg}$ intramuscularly, then four $\mathrm{mg}$ six-hourly. Within six hours he regained consciousness and though drowsy could answer questions lucidly. C.S.F. pressure five days later was $180 \mathrm{~mm}$ H.O. Despite recovery from this acute episode his renal function subsequently deteriorated, and he died four weeks later from uraemia, pulmonary

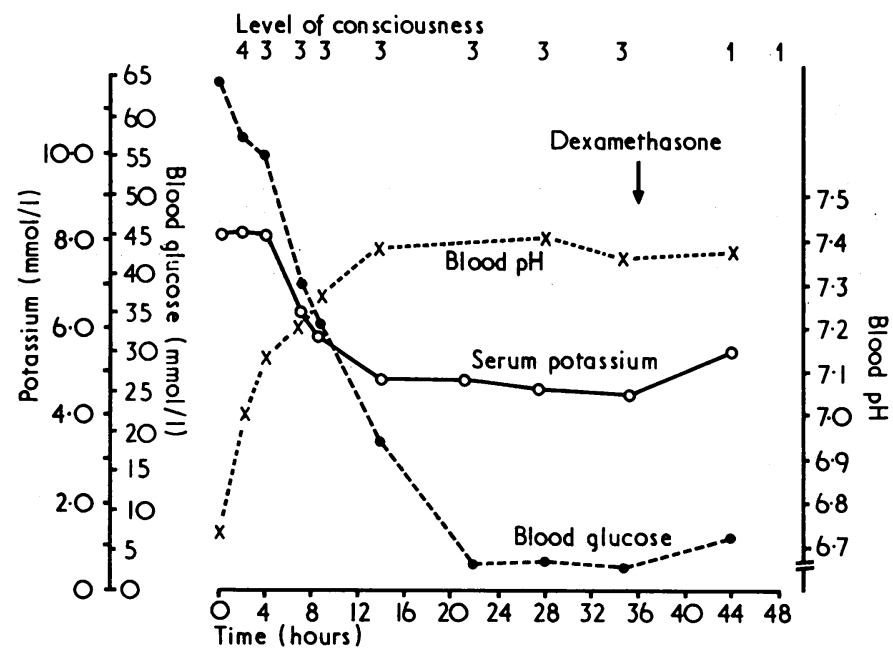

Effect of treatment on blood glucose, serum potassium, and blood $\mathrm{pH}$, with related level of consciousness (grades $0-4$ ).

Conversion: SI to Traditional Units-Glucose: $1 \mathrm{mmol} / 1 \approx 18 \mathrm{mg} / 100 \mathrm{ml}$

oedema, and bronchopneumonia. At necropsy there was no evidence of intracerebral disease.

\section{Discussion}

Cerebral oedema has been reported only in young diabetics free of major complications who did not seem dangerously ill and who lost consciousness only after treatment of the ketoacidosis was started.1 a The development of cerebral oedema may be caused by a rapid fall in blood glucose with improvement in the metabolic acidosis. ${ }^{2}$ During treatment C.S.F. glucose and osmolality are higher and fall more rapidly than those in the blood, ${ }^{4}$ and this may produce a shift of water from blood to subarachnoid space and brain because of an osmotic gradient. ${ }^{2}$ In our patient the fall in blood glucose averaged $2.8 \mathrm{mmol} \mathrm{l}^{-1} \mathrm{~h}^{-1}\left(50 \mathrm{mg} 100 \mathrm{ml}^{-1} \mathrm{~h}^{-1}\right)$, which is much less than the fall of $5.0 \mathrm{mmol}^{-1} \mathrm{~h}^{-1}\left(90 \mathrm{mg} 100 \mathrm{ml}^{-1} \mathrm{~h}^{-1}\right)$ reported by others. ${ }^{3}$ Serum osmolality fell from $351 \mathrm{mmol} / \mathrm{kg}$ to $318 \mathrm{mmol} / \mathrm{kg}$ during the first 14 hours. In ketoacidosis the depression of consciousness parallels the hyperglycaemia and the hyperosmolality rather than the degree of acidosis, ${ }^{5}$ but a profound lowering of C.S.F. $\mathrm{pH}$ resulting from changes in acid-base balance between blood and C.S.F. may contribute. ${ }^{4-5}$

The initial high C.S.F. pressure and the rapid response to dexamethasone suggest that cerebral oedema contributed significantly to the delayed return of consciousness in our patient. Spontaneous recovery is exceptional, ${ }^{2}$ and active treatment has generally been unsuccessful $^{1}$ though parenteral methylprednisolone has been used successfully in non-ketotic hyperglycaemic coma. Success of treatment may be related to the duration of cerebral oedema before treatment begins.

In an unconscious diabetic patient it may be difficult to decide when to perform a lumbar puncture. Severe retinopathy in our patient made exclusion of papilloedema impossible, and a further diagnostic problem arose from the presence of white cells in the C.S.F. This has been noted in cerebral oedema without infection after ketoacidosis ${ }^{1}$ and is presumably an epiphenomenon. Failure to recover consciousness after biochemical improvement in diabetic ketoacidosis must promote suspicion of cerebral oedema, in which early use of dexamethasone may be beneficial.

1 Young, E., and Bradley, R. F., New England Fournal of Medicine, 1967, 276, 665 .

2 Clements, R. S., et al., Lancet, 1971, 2, 671.

3 Alberti, K. G. M. M., Hockaday, T. D. R., and Turner, R. C., Lancet, $1973,2,515$.

4 Ohman, J. L., et al., New England fournal of Medicine, 1971, 284, 283.

5 Fulop, M., Tannenbaum, H., and Dreyer, N., Lancet, 1973, 2, 635.

Division of Medicine, Ninewells Hospital, Dundee DD2 1 UB

B. M. FRIER, M.B., M.R.C.P., Medical Registrar

J. B. MCCONNELL, M.B., M.R.C.P., Medical Registrar 